The method depends upon the opacity to X-rays of the two reduced valves or head plates at the anterior end of the animal, the posterior accessory pallets, and the calcareous lining which it secretes around its burrow in the wood. Since even the minute valves of the newly settled larvæ show up clearly (Fig. a) the actual onset of the attack is revealed immediately. Later radiographs show the extent of the infestation, the position of each animal and its tube being sharply defined against a background formed by the grain of the wood.

A low-power mobile X-ray set was chosen for this work as the tube had low inherent filtration and a l-mm. focus, ample contrast and resolution being obtained on Ilfex film at $40 \mathrm{kVp}$., with an exposure of $10 \mathrm{~mA} . / \mathrm{sec}$, at $30 \mathrm{in}$. focus-film distance. Using the same film, the work is possible with the smallest portable set obtainable. Infected blocks were scraped clean of surface growths and photographed in the laboratory, lead numerals serving to identify the blocks and to indicate a reference plane. The blocks were replaced in the sea within a few hours of removal for examination. In this way it has been possible not only to follow the whole course of attack in series of experiments on infected blocks, but also to obtain information on the times and preferred positions of settlement, on growth-rates, and growth habits.

With wooden blocks $\frac{1}{2}-1$ in. in thickness it was found desirable to introduce stereoscopy in order to interpret the arrangement of the burrows. A degree of hyperstereoscopy was achieved by moving the stereofilm changer along a track parallel to one side of the film through a distance equal to one-sixth of the focus-film distance instead of the normal onetenth. This gave an apparent 50 per cent increase in depth in a Wheatstone stereoscope ; with greater hyperstereoscopy there was a risk that the conglomerate images of heavily infected wood might be difficult to dissociate. In some instances fiduciary wires were placed along the two sides of the picture space to indicate a surface plane and to measure shadow shifts if required.

Stereographs of heavy infestations taken by this means give a remarkable effect, the tubes being seen in three dimensions intertwined among each other, yet every tube quite isolated from its neighbours.

A paper giving further details of the use of this technique is in course of preparation and will be published shortly.

Marine Biology Station,

$$
\text { D. J. CRISP* }
$$

University College of North Wales, Bangor.

L. W. G. JONES

Imperial Chemical Industries, Ltd.,

Paints Division,

Marine Research Station, Brixham.

Messrs. Ilford

Tavistock House, North,

Tavistock Square,

London, W.C.1.

* Formerly of Imperial Chemical Industries, Ltd., Palnts Division, Marine Research Station, Brixham.

"Isham, "L. B., Moore, Hilary B., and Waiton Smith, F. G., 136 (1951).

${ }^{2}$ Attwood, W. D., and Johnson, A. A., "Marine Structures : their Deterioration and Preservation". Fig. 13, p. 28 (National Research Council, Washington, D.C., 1924)

\section{Occurrence of Phoronis mülleri in the Irish Sea}

THE recent discovery of Phoronis mülleri de Selys Longchamps off the west coast of the Isle of Man appears to constitute the first British record of the adult of this species; according to de Selys Longchamps, the larva of Phoronis mïlleri is Actinotrocha branchiata J. Müller, which he states has been found at Millport, St. Andrews, Plymouth and Valencia ${ }^{1}$.

There have been no previous records of adults of any species of Phoronis in Manx waters; but larvæ, recorded as "Actinotrocha sp.", were found in Port Erin Bay from June to August 1899 2. The discovery of the adult Phoronis mülleri was made during quantitative investigations of the offshore polychæte fauna in November 1952. It was found to be common in muddy sand at depths of 37-62 m., and to occur occasionally down to $74 \mathrm{~m}$. in an area between four and seven miles west of the Niarbyl.

Phoronis mülleri was first described from Heligoland, where it was found in muddy sand at 35-37 m. ${ }^{\text {. }}$. It was next recorded from the west coast of Sweden, again from muddy sand, at all depths from $9 \frac{1}{2}$ to $53 \mathrm{~m}^{3}$. The latest record of which I am aware is from Danish waters, where some post larvæ were found west of the Island of Ven in the Øresund, at a depth of $16 \mathrm{~m} .4$.

Unlike the two other British species (Phoronis hippocrepia Wright and Phoronis ovalis Wright), Phoronis mülleri is not colonial and does not bore into dead shells. It builds a tube of sand up to $80 \mathrm{~mm}$. long by $1 \mathrm{~mm}$. wide which stands vertically in the substratum. The species may be distinguished from all others of the genus by the shortness of the tentacles on the oral side of the lophophore ${ }^{1, s}$.

It appears that Phoronis mïlleri is restricted to offshore grounds of muddy sand, and it is probable that it will be found to be more widely distributed than it is known to be at present.

Marine Biological Station,

Eve C. Junges

Port Erin,

Isle of Man. April 7.

de Selys Tongchamps, M., Wiss. Meeresunters., 6 (Abt. Helgoland), 1 (1903).

${ }^{2}$ Chadwick, H. C., Ann. Rep. Mar. Biol. Sta., Port Erin, 13, 32 (1899). ${ }^{8}$ Gustafson, G., Arkiv for Zoologi, 28B, 1, 1 (1935).

- Brattstrom, H., Kungl. Fysiogr. Sällsk. Handlingar., N.F., 54, 2, 16 (1943). Thorson, G., Medd. Komm. Danmarks Fiskeri-og Havunders., Ser. Plank., 4, 1, 153 (1946).

\section{Fluorine Tests in Australia on the Keilor Skull and a Tertiary Marsupial}

The Keilor Skull. The application of the fluorinephosphate method described by Oakley and Hoskins ${ }^{1}$ for determining the relative ages of fossils has shown that the Keilor Skull from near Melbourne is a true fossil, and its age that of the terrace in which it was found. The ratio $\frac{\% \mathrm{~F} \times 100}{\% \mathrm{P}_{2} \mathrm{O}_{5}}$ for the skull is $2 \cdot 0$, and of other fossils found in situ in the terrace $1 \cdot 9, \mathbf{1} \cdot \mathbf{5}$ and $2 \cdot 9$. Different parts of a rat skeleton gave $3 \cdot 8$ and $4 \cdot 4$-higher than anticipated, and due to low percentage of phosphate. I am indebted to Mr. W. R. Jewell, chief chemist, State Laboratories, Melbourne, and his staff for carrying out the analyses.

The various terraces at Keilor can now be retognized by their lithology, their spatial relationships 